\section{Prospects For The Development Of Remote Banking Services In The Context Of Bank Transformation}

\author{
Zokir Mamadiyarov
}

Head of Banking and Investment department, Ph.D., docent Tashkent State University of Economics, Uzbekistan

\section{G open ACCess}

The American Journal of Applied Sciences

JULY 2020

Page No.: 108-118

Volume-II Issue-VII

PUBLISHED: 31 JULY 2020

www.usajournalshub.com/inde x.php/tajas

Copyright: Original content from this work may be used under the terms of the Creative Commons Attribution 4.0 licence.

\begin{abstract}
The article analyzes the current trends in banking technologies and the future development of banking technologies in the process of transformation of banks around the world due to the increasing provision of banking services on the basis of remote mobile, Internet and other banking technologies. The results of this study are of practical importance for the development of remote banking services in the banking system of Uzbekistan.
\end{abstract}

Keywords: Remote banking services, digital technologies, digital banking system, API transformation, FinTechs, digital transformation.

\title{
Introduction
}

Today, the banking system is one of the most developed industries focused on technological innovation and is the main locomotive of economic development of the country. The effective functioning of the banking system of any country and its rapid adaptation to changes associated with the development of the world banking system determine the basis for the development of the country's economy. Technological developments have led to high changes in the banking system, as in all areas. Now the world banking system is changing from a traditional banking system to a digital banking system. The emergence of digital banking services as a target system has allowed consumers to offer a wide range of services. 
The introduction and use of information and communication technologies in banking will increase the popularity of banking services. According to an infographic study by Juniper Research, the number of users of digital banking and remote banking services in the world is expected to reach 2.4 billion by 2020 and increase by $54 \%$ to 3.6 billion by 2024. In 2019, banks invested heavily in digital transformation and innovation. According to Juniper Research's Digital Transformation in Banking Readiness Index, although the scale of funding for digital transformation and innovation varies, Bank of America, BBVA and JPMorgan Chase are the top three transnational banks in terms of funding for digital transformation and innovation.

Bank of America has offered a wide range of digital solutions based on Erica chatbot and intuition in the use of digital technologies, while BBVA Bank has focused on investing APIs in the bank by offering a banking service platform, the BBVA Open Platform. JPMorgan Chase has experimented with blockchain (Juniper Research 2020).

Decree of the President of the Republic of Uzbekistan DP-5992 "On the strategy of reforming the banking system of the Republic of Uzbekistan for 2020-2025" The main aspects of the decree are the introduction of modern standards, information technology and software products, the widespread introduction of remote services for the population and small business, the development of a network of low-cost service points. It is also planned to develop a strategy for reforming the banking system of the Republic of Uzbekistan for 2020-2025 to increase the popularity and quality of financial services by creating favorable conditions for the formation and development of non-bank credit institutions as a complementary part of the single financial system (DP-5992, 2020).

Therefore, in most countries of the world, effective management of banking services and remote digital technologies without visiting the bank remains one of the most important tasks today.

During the years of independence, the banks of Uzbekistan have also managed to adequately develop their services. However, competition between banks is pushing them to take a new approach to attracting more customers and expanding the range and quality of services provided.

In order to effectively organize the work in this direction, the Address of the President of the Republic of Uzbekistan to the Oliy Majlis emphasizes the need for radical reform of the banking system, transformation of banks, introduction of modern banking practices, management and new services.

In particular, the Government and the Central Bank should develop long-term strategies for the development of the banking and financial system with the support of international financial institutions.

\section{Materials and methods}

In the last global financial crisis of 2008, a large part of the problem was seen as the involvement of banks. In the context of the COVID-19 pandemic, banks can play an important role in addressing these issues. That is, banks can help their customers make 
more efficient use of digital and remote-control channels to slow the spread of COVID-19. Consequently, banks can help their customers reduce the impact of the inevitable crisis by managing their funds, making payments, and arranging continuous operations with other government agencies (Mamadiyarov, Z. 2020a).

Increasing customer demand in commercial banks and non-satisfaction of these requirements leads to a decrease in the loyalty of bank customers to their bank. As a result, bank customers try to switch banks or use other banking services. Therefore, banks need to transform their activities in accordance with the requirements of customers, that is, to create new banking services using modern information and communication technologies.

Dr. Fred Davis, of the Massachusetts Institute of Technology, noted that remote banking services can be achieved easily and conveniently for the user without any effort on the part of the user (Davis, F.D., 1989). The ease of use of remote banking services by Dr. Irwin Thomas Joseph Brown of Cape Town University influences the perception of this system as useful. On the other hand, mobile banking is easier to use, ie it is more useful to perform banking operations through a small device than a complex system. According to research, the ease of use of remote banking services also has a significant positive impact on the use of these services (Wessels, L., Drennan, J., 2010).

In Uzbekistan, many bank customers usually prefer to provide their services by visiting banks, rather than using remote banking services. This is due to the low financial literacy of bank customers and the poor quality and speed of the Internet across the country, which is one of the main reasons for the development of remote banking services.

As can be seen from Table 1, as of January 1, 2020, the number of legal entities and individual entrepreneurs using remote banking services was 98,400 in Ipoteka Bank, 96,250 in Agrobank and 91,332 in the People's Bank. The leading trio was in the bottom three, with 128 in Soderot, a subsidiary of Iran's Soderot Bank, 107 in Uzagroexportbank and only 56 in Tenge Bank.

As of January 1,2020, compared to the same period in 2019, banks that have more remote banking services for legal entities, JSCB "Qishloq Qurilish Bank" increased by $413.9 \%$ to 12 th place in the ranking, JSCB "Microcreditbank" increased by $343.9 \%$ to 6 th place in the ranking. , PJSC "Trustbank" rose 9 places in the ranking with a growth of $282.4 \%$, JSCB with FC "Savdogar" increased by $278.2 \%$ and rose to 6 th place in the ranking, and "Ipoteka-Bank" took the 1st place in the ranking with a growth of $241.8 \%$. 


\section{Table 1}

\section{Ranking of commercial banks by the number of legal entities and YTTs using remote banking services (TOP-10)}

\begin{tabular}{|c|c|c|c|c|c|c|c|c|c|}
\hline \multirow[b]{2}{*}{ № } & \multirow[b]{2}{*}{ Банк номи } & \multicolumn{2}{|c|}{01.01 .2020} & \multicolumn{2}{|c|}{01.01 .2019} & \multicolumn{4}{|l|}{ Change } \\
\hline & & Q-ty & $\begin{array}{l}\text { Share } \\
(\%)\end{array}$ & Q-ty & \begin{tabular}{|c|} 
Share \\
$(\%)$
\end{tabular} & $\begin{array}{l}\text { Growth } \\
(\%) \\
(+/-)\end{array}$ & $\begin{array}{l}\text { Share } \\
(+/-)\end{array}$ & & \\
\hline 1 & JSCMB «Ipoteka-bank» & $\begin{array}{l}98 \\
400\end{array}$ & $14,2 \%$ & $\begin{array}{l}28 \\
786\end{array}$ & $8,0 \%$ & $241,8 \%$ & $6,2 \%$ & 4 & \\
\hline 2 & JSCB «Agrobank» & $\begin{array}{l}96 \\
250\end{array}$ & $13,9 \%$ & \begin{tabular}{|l}
78 \\
981
\end{tabular} & $22,0 \%$ & $21,9 \%$ & $-8,0 \%$ & $\mathbf{1}$ & - \\
\hline 3 & JSC People's Bank & $\begin{array}{l}91 \\
332\end{array}$ & $13,2 \%$ & $\begin{array}{l}28 \\
942 \\
\end{array}$ & $8,0 \%$ & $215,6 \%$ & $5,2 \%$ & $\begin{array}{l}1 \\
1\end{array}$ & \\
\hline 4 & $\begin{array}{l}\text { JSCB with } \\
\text { «Hamkorbank» }\end{array}$ & $\begin{array}{l}69 \\
714\end{array}$ & $10,1 \%$ & \begin{tabular}{|l}
56 \\
115 \\
\end{tabular} & $15,6 \%$ & $24,2 \%$ & $-5,5 \%$ & $\mathbf{1}$ & - \\
\hline 5 & National Bank for FEA & $\begin{array}{l}52 \\
969\end{array}$ & $7,7 \%$ & $\begin{array}{l}19 \\
565\end{array}$ & $5,4 \%$ & $170,7 \%$ & $2,2 \%$ & $\mathbf{1}$ & \\
\hline 6 & JSC Mikrokreditbank & $\begin{array}{l}48 \\
152 \\
\end{array}$ & $7,0 \%$ & $\begin{array}{l}10 \\
847\end{array}$ & $3,0 \%$ & $343,9 \%$ & $4,0 \%$ & $\mathbf{1}$ & \\
\hline 7 & $\begin{array}{l}\text { JSCB } \\
\text { «Uzpromstroybank» }\end{array}$ & $\begin{array}{l}31 \\
464\end{array}$ & $4,6 \%$ & $\begin{array}{l}65 \\
491 \\
\end{array}$ & $18,2 \%$ & $-52,0 \%$ & $13,7 \%$ & 5 & - \\
\hline 8 & JSCB «Kapitalbank» & $\begin{array}{l}21 \\
519\end{array}$ & $3,1 \%$ & 6957 & $1,9 \%$ & $209,3 \%$ & $1,2 \%$ & $\mathbf{1}$ & \\
\hline 9 & PJSB «Trustbank» & $\begin{array}{l}19 \\
871\end{array}$ & $2,9 \%$ & 5197 & $1,4 \%$ & $282,4 \%$ & $1,4 \%$ & $\begin{array}{l}1 \\
6 \\
6\end{array}$ & \\
\hline 10 & JSCB «Asaka» & $\begin{array}{l}19 \\
546 \\
\end{array}$ & $2,8 \%$ & 7959 & $2,2 \%$ & $145,6 \%$ & $0,6 \%$ & 2 & - \\
\hline $\begin{array}{l}\text { Tot: } \\
\text { sys: }\end{array}$ & $\begin{array}{l}\text { al in the banking } \\
\text { tem: }\end{array}$ & $\begin{array}{l}691 \\
008\end{array}$ & $\begin{array}{l}100,0 \\
\%\end{array}$ & $\begin{array}{l}359 \\
770\end{array}$ & $\begin{array}{l}100,0 \\
\%\end{array}$ & $92,1 \%$ & & & \\
\hline
\end{tabular}

Source: Compiled by the author on the basis of the Central Bank of the Republic of Uzbekistan.

Today, the transformation of banks requires, firstly, the establishment of digital banks, and secondly, the change in the activities of existing banking divisions and the reduction of banking costs. In digital banks, banking services will be fully automated and self-management systems will be created for bank customers. In particular, today's demand is that as a result of the development of the digital economy, banks are required to serve a large number of customers not by increasing the number of branches, but by developing remote banking services.

Prior to the start of the transformation process in banks, there were a number of inconveniences in customer service. In particular: 
- international money transfers;

- currency exchange offices;

- utilities and other payments;

- opening a bank account;

- loan processing;

- opening of plastic cards and other banking services are provided to customers in separate departments (cash desks).

Now, all of this has been optimized. Customers have the opportunity to make payments (international money transfers, currency exchange offices, utilities and other payments) through a single universal cashier.

Product Delivery (channels)

\section{$57 \%$}

Product Innovation (new products)

\section{$17 \%$}

Competition/players

\section{$13 \%$}

Product Use (consumption)

\section{$11 \%$}

Other (please specify)

$2 \%$

Source: Efma-Infosys Finacle 'Innovation in Retail Banking 2019

\section{Picture 1. Areas of Most Banking Innovation}

More than half (57\%) of organizations surveyed stated that the largest focus of innovation was in the area of product delivery and delivery channels. This is in alignment with the movement to improve the digital customer experience across the industry. Not surprisingly, less than $20 \%$ of organizations are focused on product innovation. This indicates a strong focus on incremental innovation as opposed to more transformational or disruptive innovation. While improving product delivery is important, organizations must move to more aggressive innovation strategies.

Coexistence of Uzbek commercial banks with world banks paves the way for the intensification of integration and globalization. On the one hand, the development of integration processes has necessitated the use of modern information and communication technologies, and on the other hand, it has created a business transformation. The study of these processes from the economic and political point of view and drawing scientific conclusions is a requirement of the time. The digital economy is a major ally of corruption and the "black economy". Because numbers seal everything, store it in memory, provide information quickly when needed. In such circumstances, it is impossible not to hide any information, to make secret transactions, not to give full information about this or that 
Digging deeper into the data reveals a correlation between the size of an organization and the progress of digital transformation. The Innovation in Retail Banking research found that larger organizations had greater digital transformation maturity and greater success in meeting organizational objectives. Credit unions also performed better than their community and regional bank counterparts.

This article is both timely and relevant. Mobile payment ecosystems and mobile banking are currently in a period of evolutionary transition (Liu, J., Kauffman, R.J., Ma, D., 2015). Of the mobile banking adoption literature, some researches indicated that typical users of electronic banking were relatively young (Joshua \& Koshy, 2011). In particular, the use of Internet banking and mobile banking in the payment system in Uzbekistan began in 2007.

However, there are practical and theoretical problems that need to be addressed in the further development of remote banking services:

First, there is currently a lack of remote banking services and insufficient innovations in existing ones, i.e. through remote banking services, bank customers are still unable to perform all banking services without a full visit to the bank. The number of mobile subscribers in the Republic of Uzbekistan as of January 1, 2019 is more than 22.8 million, of which the number of mobile Internet users is more than 15 million. Reached 9.5 million. This means that despite the growing number of remote banking users in Uzbekistan, the low level of customer coverage still requires more work.

Second, the sharp rise in remote banking services also increases the threat of economic risks. That is, the legitimacy of the services provided to customers, the degree to which they legalize remittances, and so on.

Third, the low level of access of banks to new information technologies and low financial literacy of the population pose certain problems in the development of remote banking services.

Fourth, the creation of an automated system of cashless payments, as a result, requires the search for new modern forms and means that simplify and further accelerate the system of cash circulation.

Fifth, one of the main problems in the development of remote banking services in Uzbekistan is the confidence of the population in the banking system.

While there are many benefits to remote banking services, this poses some risks associated with confidential information, customer personal information, and transactions in new technology services.

Further development of remote banking services provided by the banking system of Uzbekistan, determining the demand of the population for such products and services through marketing services, and, consequently, making appropriate changes in the banking strategy will ensure the bank's stability and competitiveness in this market segment.

\section{Conclusion}

In conclusion, the expansion of the functional capabilities of remote banking service systems, in turn, will allow users to carry out a wide range of operations through remote identification systems. Remote identification requires security measures in the control of banking operations, simplifying banking services. For clients, it is necessary to perform 
banking services without the provision of paper documents, to be a customer of one branch of the bank, to be able to use other branches, and in the future, other banking services.

In turn, commercial banks provide customers with the opportunity to attract new customers and develop competition in the financial market as a result of reduced service costs through the provision of remote banking services. As a result, the implementation of this work will also increase the bank's income.

The introduction of new banking products and services on the basis of modern information technologies creates conditions for the expansion of the banking services market in Uzbekistan. As the market economy develops in Uzbekistan, commercial banks will also diversify their services by increasing the range of remote banking services they provide to customers.

Remote banking services cannot be imagined without terminals, ATMs and kiosks. These simple-to-use devices today serve as a kind of mini-bank-office, ending the traditional interaction between the customer and the cashier. At present, it is possible not only to withdraw cash from these external means, but also to make various payments for goods and services. It should be noted that customers can use any bank terminal, ATM and kiosk 7/24, 7 days in a week (Mamadiyarov, Z. 2020).

In particular, the concept of the Development Strategy of the Republic of Uzbekistan until 2035 divides the development of the payment system in Uzbekistan into two periods, the first period covers the period until 2020, in which the creation of banking applications, connecting customers to a single payment platform. , introduction of card reader and mobile POS terminals into the payment system, R2R settlements, data collection and creation of processing systems.

The second period covers the period up to 2025, which includes a portal for accounting and sales of goods, transaction management system, mobile banking cryptographic identifiers, integration of various services into digital platforms of banks, introduction of $\mathrm{B} 2 \mathrm{~B}, \mathrm{~B} 2 \mathrm{C}$ express transfers, open programming interface, banking The business will be able to provide banking products and services based on remote identification, artificial intelligence and the study of automated machines.

Today, traditional banking services are being replaced by digital banking services. Because if banks do not improve the range of services, they may lose the opportunity to dramatically increase revenue and the number of customers.

In order to increase the diversification of assets and liabilities of banks, it is necessary to plan to further increase its position in the retail customer segment, and in this regard should identify the following as a strategic plan:

- introduce new types of financial services on a regular basis through a proactive study of customer requirements. In addition, the establishment of asset management and financial advisory services close to banking activities;

- it is necessary to introduce express lending to small businesses, the introduction of a scoring system, the introduction of innovative online lending services;

- development of a wide range of services in the provision of banking services, such as information channels, Internet banking, mobile banking, SMS banking, Bank-client programs, self-service centers in 24/7 format;

- increase the efficiency of cross-selling operations and the introduction of specialized 
sales models in the same field.

- wide use of plastic cards in the provision of banking services, the issuance of various cards, the introduction of time deposits on plastic cards, further expansion of the network of ATMs, giving priority to areas visited by tourists and places with high demand for banking services;

- further strengthening the results achieved in the collection of utility bills from the population, improving the established relations with public utilities for the direct exchange of electronic information, the establishment of these channels in the online system;

- improving the mobile application of the bank. Launch of microcredit and overdraft loans to customers through the mobile application, introduction of international money transfers;

- organization of electronic applications for opening a card for customers through the website;

- opening an account for customers through the bank's website, arranging the repayment of loans through the personal account of individuals;

- improving the skills of bank employees in the provision of retail banking services, communication with customers and the formation of corporate culture.

\section{Conclusion}

As the crisis intensifies as a result of the pandemic, we do not know exactly how serious and lasting the problem is. It is clear that as a result of COVID-19, economic performance in 2020 will not be as planned. The payment system also needs to identify prospects for improving the payment ecosystem after the economic crisis. These are not only aspects that need to be transformed in the banking sector, but also limiting the spread of viruses, the tasks we need to perform in order for our economy to recover efficiently and in the short term. Below we make a number of suggestions on the aspects that need to be transformed banks in the context of COVID-19.

1. Use cash wisely. The use of cash as a physical payment in the context of COVID19 can be an active tool in transmitting the virus. From a security point of view, banks close their branches or work with a minimum number of employees. In this context, it is time for banks to effectively use remote banking services, develop and improve digital programs. There has been a real impetus for the use of contactless payment, card and ewallet based payment systems, especially in retail payments.

2. Ensure that the platforms are simple and accessible to all. Under COVID-19, not all customers of the bank have equal access to new software and technologies. This is particularly detrimental to the cash-only population. Therefore, the creation of an automated system of cashless payments, as a result, requires the search for new modern forms and means that simplify and further accelerate the system of cash circulation. The increase in distance purchases will have a drastic impact on the decline in sales of traders who do not use digital technologies. As a result, all legal entities and individuals who are customers of the bank should be prepared for the use of digital banking technologies.

3. It is necessary to establish a multi-sectoral payment system to support multisectoral trade. Multi-channel channel capabilities that combine physical and digital payments in any environment can play an important role in increasing the geography of users who can make all payments. 
In particular, remote banking can expand the range of services in several areas. According to the Efma-Infosys Finacle Digital Banking Report Survey 2018, by 2022, the most important communication channels for the implementation of banking services will be mobile banking, online services, digital assistants, social media, FinTechs and applications, ATMs, it consists of a call center, communication managers, bank branches and carriers. The most popular of these is mobile banking, which is expected to reach 6.56 billion users by 2022. The number of users of online services is 5.95 billion. The number of users of digital assistants, i.e. bots, voice devices, etc., is 4.93 billion. forming the body, they formed the leading trio. Even during this period, the number of users of banking services through bank branches amounted to 3.84 billion. The establishment of the body indicates the growing importance of new payment systems and new payment technologies.

4. Promoting a new era of cooperative competition. The general decline of our society is beginning a new crisis, a problem of cooperative thinking that is not typical of past crises. The liquidity and profitability crisis caused by the crisis will lead to drastic changes in the FinTechs industry and eliminate initiatives that are clearly not in line with long-term economic goals. We are confident that this development will lead to a new FinTechs landscape, creating more opportunities to develop partnerships and achieve success in the industry.

5. Changing the operating model of making payments in banks. Payment processes today are more complex and non-operational. It is a huge cost burden, especially for banks. Banks need to think about changing and improving the payment system in the wake of economic inactivity in a pandemic. Probably managing businesses that make some payments in a completely different way. For example, outsourcing for the sale or redistribution of products, cloud-based infrastructure, automation and the use of onshoring in decision-making based on analysis can be considered structural changes.

\section{References}

1.Decree of the President of the Republic of Uzbekistan No. DP-5992 of May 12, 2020 "On the strategy of reforming the banking system of the Republic of Uzbekistan for 20202025"

2.Davis, F.D., 1989. Perceived usefulness, perceived ease of use, and user acceptance of information technology. MIS Quarterly 13 (3), 318-339

3.Joshua, A. J., \& Koshy, M. P. (2011). Usage patterns of electronic banking services by urban educated customers: Glimpses from India. The Journal of Internet Banking and Commerce, 16(1), 1-12

4.Juniper Research: Digital Banking Users to Exceed 3.6 Billion Globally by 2024, as Digital-Only Banks Catalyze Market. Juniper Research's Digital Transformation Readiness Index 2020 (Graphic: Business Wire)

5.Liu, J., Kauffman, R.J., Ma, D., 2015. Competition, cooperation and regulation: understanding the evolution of the mobile payments technology ecosystem. Electron. Commer. Res. Appl. 14 (5), 372-391.

6. Mamadiyarov, Z. (2020a). Issues of further accelerating the development of remote banking services and services based on digital technologies in Uzbekistan in the context of 
the COVID-19 pandemic. Archive nauchnyx issledovaniy, 1 (24). izvlecheno ot https://journal.tsue.uz/index.php/archive/article/view/2585

7.Mamadiyarov, Z. (2020). The innovative approaches of remote banking types services in the process of transformation of banks to E-commerce. Archive nauchnyx issledovaniy, 1 (12). izvlecheno ot https://journal.tsue.uz/index.php/archive/article/view/1795

8.Wessels, L., Drennan, J., 2010. An investigation of consumer acceptance of M-banking. International Journal of Bank Marketing 28 (7), 547-568. 